\title{
EXPERIMENTAL INFECTION WITH TOXOcara cati IN PIGS: MIGRATORY PATTERN AND PATHOLOGICAL RESPONSE IN EARLY PHASE
}

\author{
Irma Estela SOMMERFELT(1), Adriana DUCHENE(2), Betina DAPRATO(1), Clara María LOPEZ(1), Natalia CARDILLO(1) \& Aníbal Juan FRANCO(1)
}

\begin{abstract}
SUMMARY
Experimental inoculations of approximately 100,000 infective Toxocara cati larval eggs were done in twelve pigs. The T. cati eggs used for inoculation were collected from cat's feces. Another group of three pigs served as an uninfected control. Groups of infected pigs were euthanized at seven, 14, 21, and 28 days post-inoculation (dpi). Tissue samples were taken for digestion and histopathology changes in early phase. The number of larvae recovered from the lungs peaked at seven and 14 dpi and were also present at 21, and 28 dpi. Larvae of $T$. cati were present in the lymph nodes of the small and large intestine at seven, 14, and 28 dpi and at seven, 14, 21, and 28 dpi respectively. In other studied tissues, no larvae or less than one larva per gram was detected. The pathological response observed in the liver and lungs at seven and $14 \mathrm{dpi}$, showed white spots on the liver surface and areas of consolidation were observed in the lungs. The lungs showed an inflammatory reaction with larvae in center at 28 dpi. In the liver we observed periportal and perilobular hepatitis. The lymph nodes of the intestines displayed eosinophil lymphadenitis with reactive centers containing parasitic forms in some of them. The granulomatous reaction was not observed in any tissues. The role of the other examined tissues had less significance. The relevance of this parasite as an etiological agent that leads to disease in paratenic hosts is evident.
\end{abstract}

KEYWORDS: Animal model; Larval recovery; Toxocara cati; Tissue lesions; Infected pig; Toxocariasis.

\section{INTRODUCTION}

Toxocara canis and Toxocara cati are common parasites of dogs and cats, respectively. Both are zoonotic agents that can cause significant disease in humans as well. Human infection with larval Toxocara produces classical visceral larva migrans; incomplete visceral larva migrans; compartmentalized forms: ocular and neurological toxocariasis; covert toxocariasis; and asymptomatic toxocariasis ${ }^{14}$.

T. cati infects both domestic and wild felines. Undeveloped eggs deposited by adult parasites are excreted in the feces of the host but are not infective in this first stage. Infective forms develop after some time in the environment. Cats can be infected by ingesting embryonated $T$. cati eggs from the soil or larvae in paratenic hosts and play a fundamental role in the dispersion of the parasite ${ }^{5,6,13,22}$. The presence of $T$. cati-infected felines $^{-1}$ in public spaces, their defecation habits, and their direct contact with humans constitute significant factors that promote the transmission of this zoonosis. A number of studies taking place worldwide have described the extent of environmental contamination with this parasite. The cat population lacks sanitary control, reproduces freely, and transforms open spaces into permanent sources of infection, thus increasing the risk of infection for the humans that spend time in these areas ${ }^{21}$.
Despite the use of several animal models and strategies to analyze the pathological tissue alterations and behavior of migrating of Toxocara spp. larvae in mammals, several controversies persist. The results of multiple studies vary based on the animal model chosen, the parasite species inoculated, and the larval dose(s) used for infection. Experimental infections with $T$. canis and $T$. cati have been described in different animal models, including mice, Mongolian gerbils, rats, and chickens $^{2,3,5,8,11,12,15,18,22,24,25}$.

Pigs are paratenic hosts of the T. cati parasite and they have many physiological similarities to humans. Pigs have been used as an animal model for the study of the Toxocariasis due to T. canis. Pigs experimentally infected with $T$. canis were previously used to study the migratory pattern of the parasite as well as to analyze the pathological changes, immunological response, and hematological disturbances triggered by infection ${ }^{3,9,15,19,20,24}$. $T$. canis is better recognized as the main cause of the toxocariasis. T. cati has been little studied as an etiological agent for human toxocariasis. STRUBE et al..$^{23}$ expressed that "No experimental infections of pigs with $T$. cati could be found in the literature; there for the migratory route of this species in this particular host remains to be determined". In this work we use pigs for studying toxocariasis due to this parasite. The objectives of this work were to study 


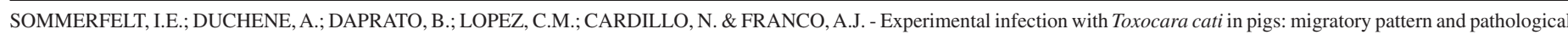
response in early phase. Rev. Inst. Med. Trop. Sao Paulo, 56(4): 347-52, 2014.

the migratory pattern of Toxocara cati larvae in the early phase of the infection in pigs and the pathological response of the tissues.

\section{MATERIALS AND METHODS}

The inoculums were prepared with $T$. cati eggs obtained from the feces of naturally infected cats. T. cati eggs were collected by brine flotation from the stools and washed in tap water. Each $2 \mathrm{~g}$ of tissue was incubated in $0.5 \%$ formaldehyde with $0.03 \mathrm{~mL}$ of iodopovidona $10 \%$ during 35 days at $28{ }^{\circ} \mathrm{C}$. They were shaken daily for eight hours. The embryonation of eggs followed weekly by light microscopy ${ }^{20}$. To evaluate the infectivity of the embryonated $T$. cati eggs, three mice were inoculated and then euthanized at one day post-inoculation (dpi). Animals were provided by the Faculty of Veterinary Sciences of the University of Buenos Aires and were housed according to the accepted standards of laboratory animal management ${ }^{1}$. The liver and lungs were processed by the acid digestion technique as previously described ${ }^{9}$. Embryonated eggs were concentrated using Benbrook's flotation technique with a saturated sugar solution. The supernatant was extracted and washed three times, with each wash followed by successive sedimentation steps by centrifugation ${ }^{7}$. Each inoculum contained approximately 100,000 eggs in one $\mathrm{mL}$ of saline solution $(0.9 \mathrm{~N} \mathrm{NaCl})$. The experimental protocol was approved by the Institutional Committee for the Care and Use of Laboratory Animals, Faculty of Veterinary Science, University of Buenos Aires.

Fifteen 40-day-old male Yorkshire pigs weighing $18 \mathrm{~kg}$ each were obtained from a swine production facility with excellent health conditions. Four groups of three animals were randomly chosen to receive the inoculums and the remaining group was designated as the uninfected control. Prior to inoculation, pigs were fasted for 12 hours. Each one $\mathrm{mL}$ inoculum was administered orally using a syringe. The syringe was then washed with two $\mathrm{mL}$ of saline solution, which was also given to the animal. Control animals received one $\mathrm{mL}$ of saline solution in a similar manner. All animals were examined clinically once a week. The experimental protocol was approved by the Institutional Committee for the Care and Use of Laboratory Animals, Faculty of Veterinary Science, University of Buenos Aires, and animals were maintained according to accepted standards ${ }^{1}$.

Groups of three infected pigs were euthanized by standard methods ${ }^{1}$ at seven, 14, 21, and $28 \mathrm{dpi}$ and were subsequently analyzed by necropsy. The control group was euthanized at $28 \mathrm{dpi}$. Each organ and tissue was weighed, and $100 \mathrm{~g}$ samples were randomly selected and divided into two halves. Organs and tissues including liver, lungs, kidneys, heart, eyes, brain, tongue, skeletal muscles and lymph nodes of the small and large intestines were collected. Eyes of each pig were sent one for pathological observation and the other for artificial digestion.

Macroscopic analysis was performed at necropsy. Microscopic evaluation of the selected organs and tissues was performed according to the technique previously described ${ }^{20}$. Each $50 \mathrm{~g}$ sample of tissue had been submerged in $10 \%$ formaldehyde and then processed for histopathology. One eye from each animal was entirely analyzed.

The artificial digestion method previously described ${ }^{9}$ was used to recover $T$. cati larvae from each $50 \mathrm{~g}$ sample of tissues. One eye from each animal was completely digested. A volume of $0.3 \mathrm{~mL}$ of concentrated material was observed under a light microscope $(10 \mathrm{x})$, and the total number of larvae was recorded. The number of larvae per gram of tissue in each sample and the total weight of each organ was used to estimate the number of larvae present in each organ.

The recovery of larvae from tissues at different time points was analyzed using a non-parametric test (Kruskal-Wallis chi-square approximation). In cases in which the time effect was significant, ANOVA (analysis of variance) and polynomial contrasts were used. The level of significance was set at $5 \%$ ( $p$-values $<0.05)$. InfoStat software was used for all statistical analyses.

\section{RESULTS}

T. cati larvae were recovered from tissues of all the inoculated pigs (Table 1). An evaluation of the number of larvae recovered from the lungs showed a significant difference among seven, 14, 21, and 28 dpi $\left(\mathrm{X}^{2}=8.3497 ; p=0.0393\right)$ that can be explained by a significant linear trend $(p=0.002)$ that describes the greater recovered at seven and $14 \mathrm{dpi}$. Larva recovery from the lymph nodes of the small intestine peaked at 14 dpi, and significant differences among seven, 14, 21, and 28 dpi were detected $\left(X^{2}=9.0702, p=0.0284\right)$, also explained by a significant linear trend $(p=0.0009)$. Larva recovery from the lymph nodes of the large intestine peaked at seven dpi, and statistical analysis detected significant differences among seven, 14,21 , and $28 \mathrm{dpi}\left(\mathrm{X}^{2}=8.5556, p=0.0358\right)$ with a significant linear trend $(p=0.0013)$. An evaluation of the number of larvae recovered from the liver, brain, kidneys, heart, muscle, and eyes showed no significant differences among seven, 14, 21, and 28 dpi. No larvae were recovered from any tissue of the control animals.

Macroscopic lesions on the lungs with areas of consolidation over the entire surface were visible at seven and $14 \mathrm{dpi}$, but these lesions decreased at 21 and 28 dpi. Microscopic lesions were observed throughout the experiment. At seven dpi, the lungs displayed an inflammatory reaction consisting of a mixture of mononuclear and polymorphonuclear cells (lymphocytes, plasmocytes, and eosinophils). We detected multifocal nodular pneumonia and an accumulation of eosinophils at $14 \mathrm{dpi}$. Non-suppurative diffuse pneumonia with a lymphoid hyperplasia focus containing lymphocytes, plasmocytes, and eosinophils was observed at 21 and 28 dpi. Larvae were present at the center of the lesion at 28 dpi (Fig. 1).

At seven and $14 \mathrm{dpi}$, macroscopic lesions on the liver had small white spots 2-3 $\mathrm{mm}$ in diameter on its surface; very few spots were detected at 21 or 28 dpi. Microscopically we observed periportal and perilobular hepatitis with a predominance of leukocytes, lymphocytes, and plasmocytes in infected pigs, along with a smaller proportion of eosinophils at seven and 14 dpi (Fig. 2).

Macroscopically, the lymph nodes of the small and large intestines were slightly edematous at seven and $14 \mathrm{dpi}$ but were normal at the other time points. Microscopically, a granulomatous reaction with larvae in the pericapsular external zone of the lymph nodes was visible at seven and 14 dpi (Fig. 3), and giant cells were also present. Such lesions were not detected at 21 or 28 dpi. The Splendore-Hoeppli phenomenon, observed in some fungal and parasitic diseases as the result of a local antigen-antibody complex formation, was detected in lymph nodes and was characterized by the deposition of amorphous eosinophilic hyaline material around the larvae (Fig. 4). 


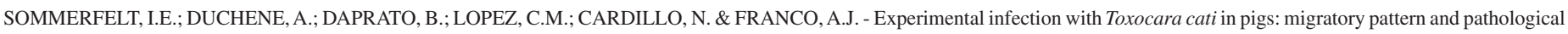
response in early phase. Rev. Inst. Med. Trop. Sao Paulo, 56(4): 347-52, 2014

Table 1

Mean number of $T$. cati larvae recovered per gram of tissues at euthanized time points, in tissues of pigs experimentally infected with 100,000 T. cati eggs

\begin{tabular}{|c|c|c|c|c|}
\hline \multirow{2}{*}{ Tissues } & \multicolumn{4}{|c|}{ Days post-inoculation } \\
\hline & 7 & 14 & 21 & 28 \\
\hline Lung & $\begin{array}{c}18.98 \pm 7.20^{\mathrm{a}} \\
(11-25)\end{array}$ & $\begin{array}{c}19.77 \pm 5.34^{\mathrm{a}} \\
(14.32-25)\end{array}$ & $\begin{array}{c}0.91 \pm 0.81^{\mathrm{a}} \\
(0.07-1.71)\end{array}$ & $\begin{array}{c}3.17 \pm 4.19^{\mathrm{a}} \\
(0.65-8.02)\end{array}$ \\
\hline Lymph nodes $(\mathrm{SI}) *$ & $\begin{array}{c}6.30 \pm 5.08^{a} \\
(0.78-10.8)\end{array}$ & $\begin{array}{c}13.25 \pm 17.28^{\mathrm{a}} \\
(2.76-33.2)\end{array}$ & 0 & $\begin{array}{c}0.16 \pm 0.27^{\mathrm{a}} \\
\quad(0-0.48)\end{array}$ \\
\hline Lymph nodes $(\mathrm{LI})^{* *}$ & $\begin{array}{c}15.88 \pm 8.11^{\mathrm{a}} \\
(7-22.9)\end{array}$ & $\begin{array}{c}10.25 \pm 13.71^{\mathrm{a}} \\
(0.93-26)\end{array}$ & $\begin{array}{c}0.21 \pm 0.36^{\mathrm{a}} \\
\quad(0-0.63)\end{array}$ & $\begin{array}{c}0.29 \pm 0.29^{\mathrm{a}} \\
(0-0.59)\end{array}$ \\
\hline Liver & 0 & $\begin{array}{c}0.05 \pm 0.05^{\mathrm{a}} \\
\quad(0-0.10)\end{array}$ & $\begin{array}{c}0.13 \pm 0.23^{\mathrm{a}} \\
(0-0.40)\end{array}$ & $\begin{array}{c}0.01 \pm 0.02^{\mathrm{a}} \\
\quad(0-0.03)\end{array}$ \\
\hline Brain & $\begin{array}{c}0.0 \pm 0.01^{\mathrm{a}} \\
(0-0.02)\end{array}$ & $\begin{array}{c}0.02 \pm 0.04^{\mathrm{a}} \\
(0-0.08)\end{array}$ & $\begin{array}{c}0.01 \pm 0.02^{\mathrm{a}} \\
(0-0.05)\end{array}$ & $\begin{array}{c}0.02 \pm 0.03^{\mathrm{a}} \\
(0-0.06)\end{array}$ \\
\hline Kidney & $\begin{array}{c}0.09 \pm 0.01^{\mathrm{a}} \\
(0.08-0.11)\end{array}$ & $\begin{array}{c}0.15 \pm 0.25^{\mathrm{a}} \\
\quad(0-0.45)\end{array}$ & 0 & 0 \\
\hline Heart & $\begin{array}{l}0.02 \pm 0.02^{\mathrm{a}} \\
\quad(0-0.04)\end{array}$ & 0 & 0 & 0 \\
\hline Muscle & $\begin{array}{c}0.40 \pm 0.33^{\mathrm{a}} \\
(0.02-0.64)\end{array}$ & $\begin{array}{c}0.99 \pm 1.20^{\mathrm{a}} \\
(0.18-2.37)\end{array}$ & $\begin{array}{c}0.05 \pm 0.04^{\mathrm{a}} \\
(0.01-0.10)\end{array}$ & $\begin{array}{c}0.59 \pm 0.35^{\mathrm{a}} \\
(0.37-1.0)\end{array}$ \\
\hline Eyes & 0 & 0 & 0 & $\begin{array}{c}0.02 \pm 0.02^{\mathrm{a}} \\
(0.01-0.05)\end{array}$ \\
\hline
\end{tabular}

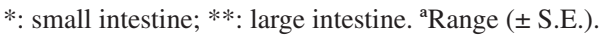

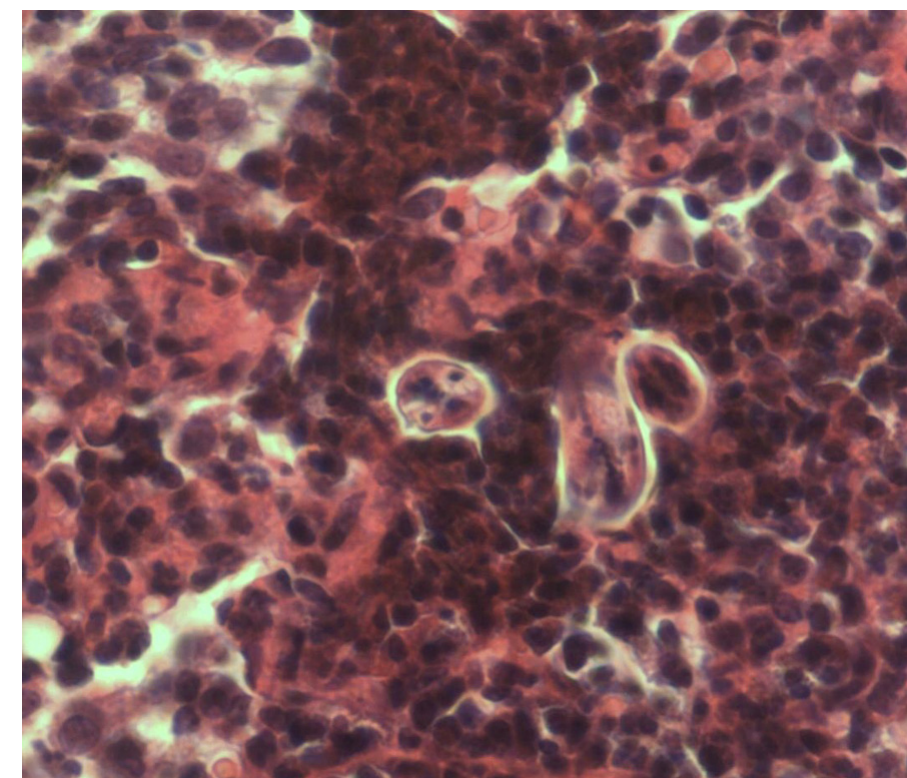

Fig. 1 - Lung tissue from a pig experimentally infected with 100,000 T. cati eggs, showing infiltration of eosinophils with larvae in the center $(\mathrm{E} / \mathrm{H} 40 \mathrm{x})$.

No macroscopic lesions were observed in the tongue. Tongues from infected pigs displayed microscopic lesions with non-suppurative and segmental myositis accompanied by leukocytes, lymphocytes, plasmocytes, and a small number of eosinophil cells at 14 and 28 dpi.

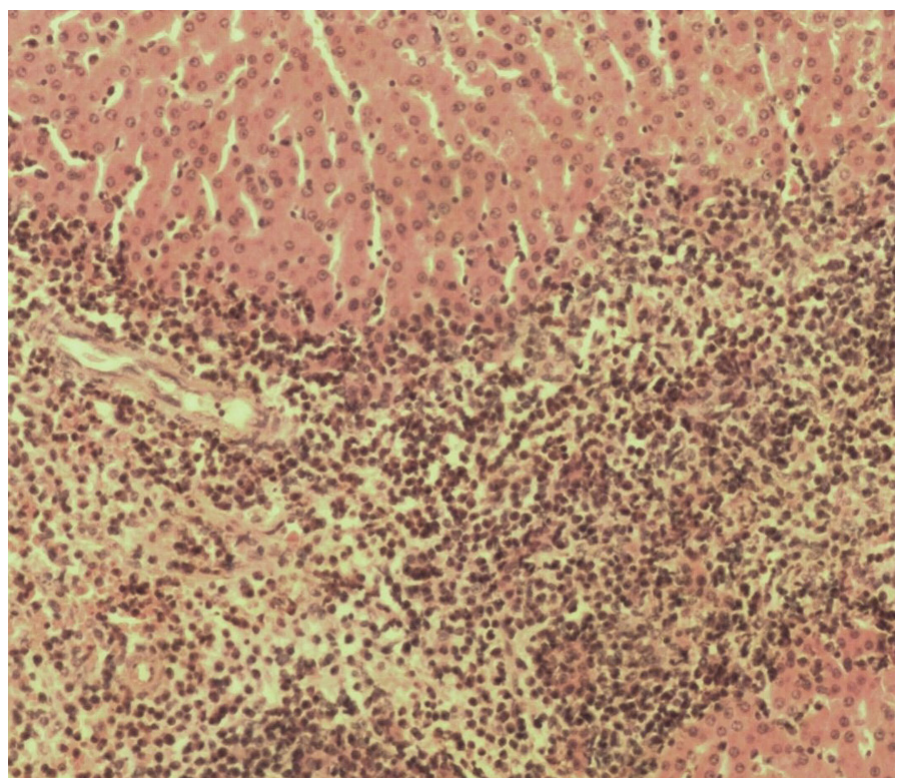

Fig. 2 - Liver tissue from a pig experimentally infected with 100,000 T. cati eggs, showing infiltration of lymphocytes, plasmocytes, and a small number of eosinophils (E/H 10x).

No macroscopic lesions were observed in the kidneys. Microscopic images of the kidneys showed focal non-suppurative interstitial nephritis at 14,21 and 28 dpi.

Muscle did not present macroscopic alterations. Microscopically, 


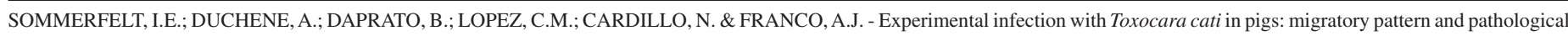
response in early phase. Rev. Inst. Med. Trop. Sao Paulo, 56(4): 347-52, 2014.

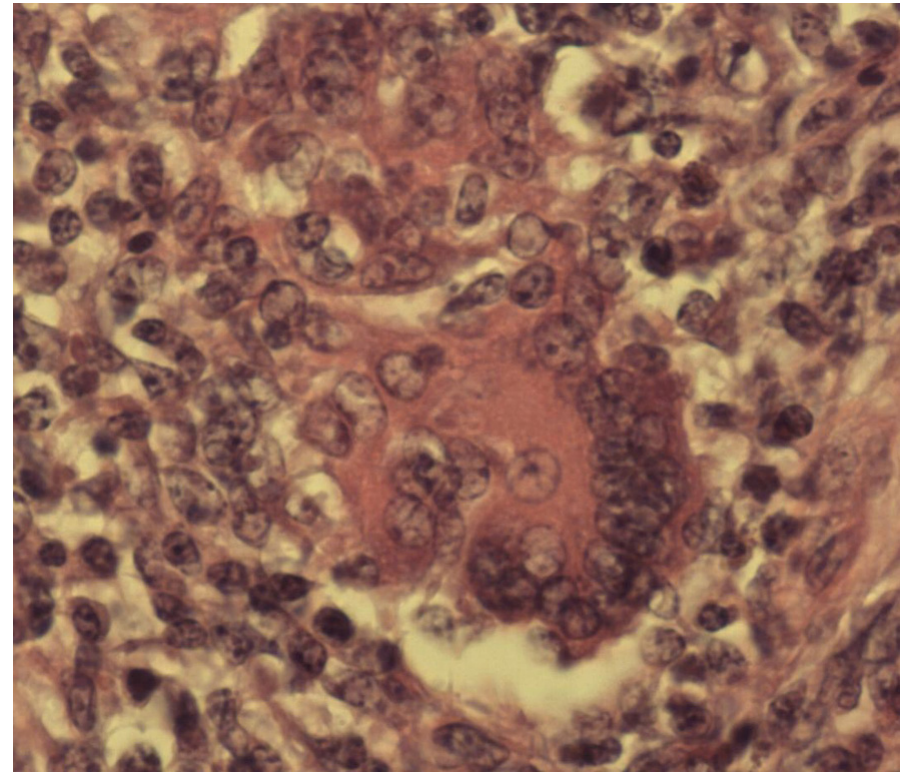

Fig. 3 -Lymph node tissue from a pig experimentally infected with 100,000 T. cati eggs, showing a reactive center in the follicle lymphoid with giant cells $(\mathrm{E} / \mathrm{H} 40 \mathrm{x})$.

several myositis foci with accumulated lymphocytes and eosinophils were observed at 14 dpi.

Pathological lesions were not detected in the brain or eyes.

In any tissue of the pigs infected with $T$. cati, the typical granulomatous reaction composed of a mixture of eosinophils, lymphoid cells, and epithelial cells surrounding a central necrotic core containing visible larvae was not observed.

No pathological lesions were observed in the control animals.

\section{DISCUSSION}

This study is the first to quantify larvae recovered from $T$. catiinfected pig tissues by using digestion techniques. The histological observations previously reported by RONÉUS ${ }^{16}$ demonstrated the presence of $T$. cati larvae in inoculated pigs but did not quantify the larvae present in various tissues.

Here, the highest numbers of larvae in the early stages of infection were recovered from the lungs and the lymph nodes of the large and small intestines (seven and $14 \mathrm{dpi}$ ). The remarkably high persistence of larvae in the lungs throughout the study indicates a predilection of $T$. cati larvae to migrate to the lungs. The lymph nodes also appeared to be another preferred site in the migratory pattern of the parasite. We also observed the persistence of $T$. cati larvae in pig muscles. $T$. cati larvae have been shown to accumulate and persist in diverse organs, depending on the animal model used to study its migratory patterns ${ }^{2,3,5,8,11,12,15,18,22,25}$.

In pigs, DONE et al. ${ }^{4}$ reported that $T$. canis larvae have been previously shown to migrate primarily to the liver and lungs; HELWIGH et al. ${ }^{10}$ and TAIRA et al..$^{24}$, to the lungs and lymph nodes; SOMMERFELT et $a t .^{20}$ observed to the lymph nodes, liver, and lungs. Therefore, lungs

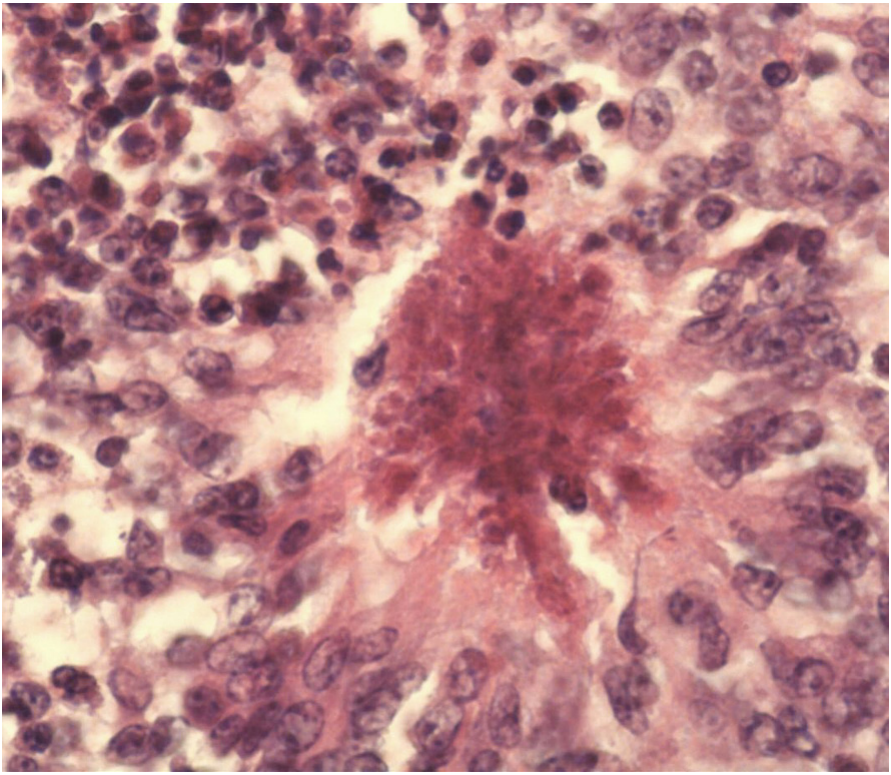

Fig. 4 - Lymph node tissue from a pig experimentally infected with 100,000 T. cati eggs, showing the Splendore-Hoeppli phenomenon (E/H 40x).

and lymph nodes are the most frequent sites for both $T$. canis and $T$. cati parasites during migration through the host. We found macroscopic lesions in the liver and lungs, in agreement with RONÉUS ${ }^{16}$. However, previous study also described changes in the kidneys ${ }^{16}$ that we did not observe in the present study. In the lungs, microscopic lesions were detected early in the infection and persisted throughout the study. This observation is in contrast with RONÉUS ${ }^{16}$, who reported that lung lesions appeared, later in the infection. However, the results of our study agree with those of RONÉUS ${ }^{16}$ in regard to the liver lesions; both studies showed periportal and perilobular hepatitis and demonstrated that the severity of the liver lesions depends on the time at which they were examined.

The data from this study and previous reports suggest a type of larval migratory pattern in which the larvae reach the lungs and the liver by migrating through the mesenteric lymph nodes. Previous reports of macroscopic or microscopic lesions produced by $T$. cati in other animal models are somewhat in agreement with our observations of lesions in lungs, liver, kidneys, and muscle $e^{2,3,5,11,22}$. Our results also agree with previous observations of macroscopic lesions in pigs inoculated with $T$. canis $^{4,10,17,20}$. White spots on the liver were also observed by TAIRA et $a l .{ }^{24}$. One notable difference between our study and previous research that inoculated T. canis, was the absence of the typical granulomatous reaction in our sample.

In conclusion, the results of this study show that the $T$. cati parasite is able to migrate through diverse tissues of the pig. Therefore, the relevance of this parasite as an etiological agent that leads to disease in paratenic hosts is evident. In our animal model, the pig, the parasite primarily migrated to the lungs and the lymph nodes. The migration of the larvae to the eyes observed in our research suggests its participation in the production of ocular larva migrans. The absence of the typical granulomatous reaction in tissues should be studied further to evaluate its influence on the immune response to $T$. cati infection and compare with the response of $T$. canis where the granulomatous reaction was present ${ }^{19,20}$. 


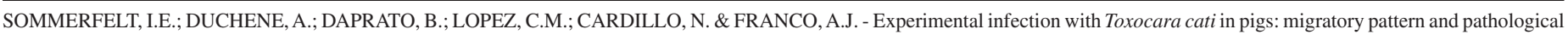
response in early phase. Rev. Inst. Med. Trop. Sao Paulo, 56(4): 347-52, 2014.

Our study contributes to the knowledge of the migratory behavior of $T$. cati larvae in pigs that could help for the comprehension of this parasite distribution on other paratenic host, as humans and to elucidate relevance of the host-parasite relationships especially in human toxocariasis.

\section{ETHICAL STANDARDS}

The experimental protocol was approved by the Institutional Committee for the Care and Use of Laboratory Animals, Faculty of Veterinary Science, University of Buenos Aires. Argentina.

\section{CONFLICT OF INTEREST}

The authors have declared that no competing interests exist.

\section{RESUMEN}

\section{Infección experimental en cerdos con Toxocara cati: patrón migratorio y respuesta patológica en etapa temprana}

Se realizó la infección experimental de doce cerdos con aproximadamente 100.000 huevos infectivos de Toxocara cati. Los huevos de $T$. cati utilizados en la inoculación fueron recolectados de heces felinas. Otro grupo de tres cerdos no infectados se utilizó como control. Grupos de cerdos infectados se eutanaciaron a los 7,14,21 y 28 días posinoculación (pi). Se tomaron muestras de tejidos para digestión y evaluación de cambios histopatológicos en la etapa temprana de la infección. El número de larvas recuperadas de los pulmones se incrementó en los días 7 y 14 pi, recuperándose también los días 21 y 28 pi. Se encontraron larvas de $T$. cati en los linfonódulos del intestino delgado y grueso los días 7,14 y 28 pi y los días 7,14,21 y 28 pi respectivamente. En los restantes tejidos estudiados o no se recuperaron larvas o los valores fueron menores a una larva por gramo de tejido. La respuesta patológica observada en el hígado y los pulmones a los 7 y 14 días posinoculación, mostró en la superficie del hígado manchas blancas y en los pulmones áreas de consolidación. Los pulmones presentaron una reacción inflamatoria con presencia de larva en el centro en el día 28 pi. En el hígado se observó una hepatitis periportal y perilobular. Los linfonódulos del intestino presentaron una linfoadenitis eosinofílica con un centro reactivo conteniendo formas parasitarias en algunos de ello. En ninguno de los tejidos se observó la típica reacción granulomatosa. El rol de los restantes tejidos examinados fue de menor significancia. Queda evidenciada la importancia de éste parasito como un agente etiológico que desarrolla la enfermedad en hospederos paraténicos.

\section{ACKNOWLEDGEMENTS AND FINANCIAL SUPPORT}

This research was supported by the University of Buenos Aires, Secretary of Science and Technique. Argentina (Research number 20020100100387).

\section{AUTHORS CONTRIBUTIONS}

Conceived and designed the experiments: I E Sommerfelt, A J Franco. Performed the experiments: I E Sommerfelt, A Duchene, B Daprato, C M López, N Cardillo, A J Franco. Analyzed the data: C M López, I E Sommerfelt. Contributed reagents/materials/analysis tools: A Duchene,
N Cardillo, B Daprato, I E Sommerfelt, C M López, A J Franco. Wrote the paper: I E Sommerfelt.

\section{REFERENCES}

1. American Veterinary Medical Association. 1993 report of the AVMA panel on euthanasia. J Am Vet Med Assoc. 1993;202:229-49.

2. Azizi S, Oryan A, Sadjjadi SM, Zibaeri M. Histopathologic changes and larval recovery of Toxocara cati in experimentally infected chickens. Parasitol. Res. 2007; $102: 47-52$

3. Cardillo N, Rosa A, Ribicich M, López C, Sommerfelt I. Experimental infection with Toxocara cati in BALB/c mice, migratory behaviour and pathological changes. Zoonoses Public Health. 2008;56:198-205.

4. Done JT, Richardson MD, Gibson TE. Experimental visceral larva migrans in the pigs. Res Vet Sci. 1960;1:133-51.

5. Dubey JP. Migration of Toxocara cati larvae in mice. Trop Geogr Med. 1968;20:172-6.

6. Dubinský P, Havasiová-Reiterová K, Petko B, Hovorka I, Tomasovicocá O. Role of small mammals in the epidemiology of toxocariasis. Parasitology. 1995;110(Pt2):18793.

7. Fan CK, Lin YH, Du WY, Su KE. Infectivity and pathogenicity of 14-month-cultured embryonated eggs of Toxocara canis in mice. Vet Parasitol. 2003;113:145-55.

8. Fisher M. Toxocara cati: an underestimated zoonotic agent. Trends Parasitol $2003 ; 1: 167-70$

9. Gamble HR, Bessonov AS, Cuperlovic K, Gajadhar AA, van Knapen F, Noerckler $\mathrm{F}$, et al. International commission on trichinellosis: recommendations on methods for the control of Thichinella in domestic and wild animals intended for human consumption. Vet Parasitol. 2000;93:393-408.

10. Helwigh AB, Lind P, Nansen P. Visceral larva migrans: migratory pattern of Toxocara canis in pigs. Int J Parasitol. 1999;29:559-65.

11. Hrckova G, Velebný S, Tomasovicová O, Medvedóvá M, Pajerský A Pathomorphological changes in mice infected with Toxocara cati following administration of fenbendazole and glucan. Acta Parasitol. 2000;46:313-20.

12. Okoshi S, Usui M. Experimental studies on Toxascaris leonina. VI. Experimental infection on mice, chickens and earthworms with Toxascaris leonina, Toxocara canis and Toxocara cati. Nihon Juigaku Zasshi. 1968;30:151-66.

13. Parsons JC. Ascarid infections of cats and dogs. Vet Clin North Am Small Anim Pract. 1987; 17:1307-39.

14. Pawlowski Z. Toxocariasis in humans: clinical expression and treatment dilemma. J Helminthol. 2001;75:299-305.

15. Prokopic J, Figallová SV. Migration of some roundworm species in experimentally infected white mice. Folia Parasitol (Praha). 1982;29:309-13.

16. Ronéus O. Parasitic liver lesions in swine, experimentally produced by visceral larva migrans of Toxocara cati. Acta Vet Scand. 1963;4:170-96.

17. Ronéus O. Studies on the aetiology and pathogenesis of white pots in the liver of pigs. Acta Vet Scand. 1966;7(Suppl. 16):1-112.

18. Schön J, Stoye M. Prenatal and galactogenic infections with Toxocara mystax Zeder, 1800 (Anisakidae) in the mouse. Zentralbl Veterinamed B. 1986;33:397-412.

19. Sommerfelt IE, Santillán G, López C, Ribicich M, Franco A. Immunological and hematological response in experimental Toxocara canis-infected pigs. Vet Parasitol. 2001;96:127-34. 
SOMMERFELT, I.E.; DUCHENE, A.; DAPRATO, B.; LOPEZ, C.M.; CARDILLO, N. \& FRANCO, A.J. - Experimental infection with Toxocara cati in pigs: migratory pattern and pathological response in early phase. Rev. Inst. Med. Trop. Sao Paulo, 56(4): 347-52, 2014.

20. Sommerfelt IE, Rosa A, Duchene A, Degregorio O, López C, Pisanú A, et al. Toxocara canis in experimentally infected pigs: migratory pattern and tissue lesions. Vet Parasitol. 2004;125:323-34.

21. Sommerfelt IE, Cardillo N, López C, Ribicich M, Gallo C, Franco A. Prevalence of Toxocara cati and other parasites in cats' faeces collected from the open spaces of public institutions: Buenos Aires, Argentina. Vet Parasitol. 2006;140:296-301.

22. Sprent JFA. The life history and development of Toxocara cati (Schrank 1788) in the domestic cat. Parasitology. 1956;46:54-78.

23. Strube C, Heuer L, Janecek E. Toxocara spp.infections in paratenic hosts. Vet Parasitol. 2013; 193:375-89.
24. Taira K, Saeed I, Lind P, Murrell KD, Kapel CMO. Population dynamics of Toxocara canis in pigs receiving a single or multiple infection. Parasitology. 2003;127(Pt 6):593-602.

25. Zibaei M, Sadjjadi SM, Uga S. Experimental Toxocara cati infection in gerbils and rats. Korean J Parasitol. 2010;48:331-3.

Received: 20 September 2013

Accepted: 21 November 2013 